\title{
Assessment of environmental stresses for enhanced microalgal biofuel production - an overview
}

\section{Dan Cheng* and Qingfang He*}

Department of Applied Science, University of Arkansas at Little Rock, Little Rock, AR, USA

\author{
Edited by: \\ Qiang Wang, Chinese Academy of \\ Sciences, China \\ Reviewed by: \\ Anoop Singh, Denmark Technical \\ University, Denmark \\ Umakanta Jena, Desert Research \\ Institute, USA

\section{*Correspondence:} \\ Dan Cheng and Qingfang He, \\ Department of Applied Science, \\ University of Arkansas at Little Rock, \\ 2801 South University Avenue, Little \\ Rock, AR 72204, USA \\ e-mail:dxcheng@ualr.edu; \\ qfhe@ualr.edu
}

Microalgal biofuels are currently considered to be the most promising alternative to future renewable energy source. Microalgae have great potential to produce various biofuels, including biodiesel, bioethanol, biomethane, and biohydrogen. Cultivation of biofuelproducing microalgae demands favorable environmental conditions, such as suitable light, temperature, nutrients, salinity, and $\mathrm{pH}$. However, these conditions are not always compatible with the conditions beneficial to biofuel production, because biofuel-related compounds (such as lipids and carbohydrates) tend to accumulate under environmental-stress conditions of light, temperature, nutrient, and salt. This paper presents a brief overview of the effects of environmental conditions on production of microalgal biomass and biofuel, with specific emphasis on how to utilize environmental stresses to improve biofuel productivity. The potential avenues of reaping the benefits of enhanced biofuel production by environmental stresses while maintaining high yields of biomass production have been discussed.

Keywords: microalgae, biofuel, environment, stress, biomass

\section{INTRODUCTION}

The rapid increase in global energy demand is driving the efforts to develop renewable energy sources. Biofuels are considered to be one of the most viable alternative sources of energy, as they are renewable, sustainable, and environment-friendly. The production of biofuels from microalgae has captured considerable interest in recent years (Schenk et al., 2008; Wijffels and Barbosa, 2010). In this review, microalgae are defined as unicellular and simple multicellular photosynthetic microorganisms, which include eukaryotic microalgae and cyanobacteria. Several attractive characters make microalgae the most hopeful feedstock for biofuel generation ( $\mathrm{Hu}$ et al., 2008; Li et al., 2008b):

(1) rapid growth, which provides high biomass productivity and reduces the time for development of such biofuel-producing systems;

(2) high amount of lipids, which can be used to produce biodiesel (Chisti, 2007; Rodolfi et al., 2009; Scott et al., 2010);

(3) the tolerance to marginal lands, which avoids competing with agricultural lands (Costa and de Morais, 2011; Day et al., 2011; Quintana et al., 2011);

(4) greenhouse gas (carbon dioxide) sequestration capacity, which can mitigate global warming impacts (Ono and Cuello, 2007; Packer, 2009);

(5) the ability to utilize nutrients (such as nitrogen and phosphorus) from polluted municipal, industrial, and agricultural wastewater, which provides economical and environmental benefits of wastewater bioremediation (Hall et al., 1995; Mulbry et al., 2008; de Godos et al., 2009; Markou and Georgakakis, 2011; Rawat et al., 2011);

(6) the potential of producing various valuable co-products for commercial application (Radmer and Parker, 1994; Olaizola,
2003; Gavrilescu and Chisti, 2005; Singh et al., 2005; Walker et al., 2005; Spolaore et al., 2006; Raja et al., 2008), which also improves the economics of microalgal biofuel production.

Microalgae are able to produce diverse forms of biofuels including: microalgal lipid-derived biodiesel (Schenk et al., 2008; Scott et al., 2010), bioethanol by fermentation of carbohydrate (Deng and Coema, 1999; Dismukes et al., 2008), biomethane through anaerobic digestion (Sialve et al., 2009; Alzate et al., 2012), and biohydrogen from photosynthesis or fermentation (Benemann, 2000; Kapdan and Kargi, 2006; Hemschemeier et al., 2009). Moreover, the whole microalgae can be converted into bio-oil (via hydrothermal liquefaction and pyrolysis), hydrochar (via hydrothermal carbonization), and syngas (via gasification) (Miao et al., 2004; Amin, 2009; Heilmann et al., 2010; Jena and Das, 2011; Jena et al., 2011; Markou et al., 2012a; Broch et al., 2014).

Although microalgal biofuels hold great promise, considerable challenges exist for their commercialization. Further research efforts required to make microalgal biofuels cost-effective and sustainable include: selecting and bioengineering microalgal strains for the best biofuel producers; optimizing culturing conditions for microalgal biomass and biofuel production; developing bioreactors suitable for large-scale microalgae cultivation; improving efficiency of microalgal biomass harvesting and downstream processing, and reducing production costs and energy consumption (Greenwell et al., 2010; Scott et al., 2010; Gong and Jiang, 2011; Nigam and Singh, 2011; Singh et al., 2011a,b, 2012).

Cultivation of microalgae for biofuel production is influenced by numerous environmental factors, including physical factors, such as light and temperature and chemical factors, such as nutrients, salinity, and pH (Hu, 2004; Guschina and Harwood, 2006; Hu et al., 2008; Singh and Dhar, 2011). These environmental factors 
not only affect the accumulation of biomass but also influence the biochemical composition of cell, and thus the biofuel productivity.

This review highlights environmental conditions required for optimized microalgae cultivation as well as stressed conditions applied for improved microalgal biofuel production.

\section{ENVIRONMENTAL FACTORS AFFECTING MICROALGAL BIOMASS ACCUMULATION}

The microalgal biomass production can be highly influenced by light intensity, temperature, nutrient availability, salinity, and $\mathrm{pH}$ (Table 1; Figure 1), as these conditions affect profoundly

Table 1 | Impact of environmental stresses on microalgal biomass accumulation and biochemical composition for biofuels.

\begin{tabular}{|c|c|c|c|c|c|c|c|}
\hline \multirow[t]{2}{*}{ Microalgae } & \multicolumn{2}{|c|}{$\begin{array}{l}\text { Biomass } \\
\text { productivity } \\
\left(\mathrm{mg} \mathrm{l}^{-1} \mathrm{~d}^{-1}\right)\end{array}$} & \multicolumn{3}{|c|}{$\begin{array}{l}\text { Biochemical content } \\
\text { ( } \% \text { of dry cell weight) }\end{array}$} & \multirow[t]{2}{*}{$\begin{array}{l}\text { Environmental } \\
\text { stresses }\end{array}$} & \multirow[t]{2}{*}{ Reference } \\
\hline & $\begin{array}{l}\text { Before } \\
\text { stress }\end{array}$ & $\begin{array}{l}\text { After } \\
\text { stress }\end{array}$ & & $\begin{array}{l}\text { Before } \\
\text { stress }\end{array}$ & $\begin{array}{l}\text { After } \\
\text { stress }\end{array}$ & & \\
\hline Arthrospira (Spirulina) platensis & 193 & 87 & Carbohydrate & 11 & 67 & Phosphorous limitation & Markou et al. (2012b) \\
\hline Nannochloropsis sp. & 633 & 457 & & 8 & 11 & High carbon dioxide & Hu and Gao (2003) \\
\hline \multirow[t]{2}{*}{ Scenedesmus obiquus CNW-N } & 441 & 841 & & 16 & 38 & High light & Ho et al. (2012) \\
\hline & 841 & 732 & & 38 & 52 & Nitrogen limitation & Ho et al. (2012) \\
\hline Spirulina sp. & - & - & & 14 & 21 & High temperature & Ogbonda et al. (2007) \\
\hline Tetraselmis subcordiformis & - & - & & $<10$ & 32 & Nitrogen limitation & Ji et al. (2011) \\
\hline Chaetoceros muelleri & 70 & - & Lipid & 19 & 36 & Silicon limitation & Griffiths and Harrison (2009) \\
\hline Chlorella vulgaris & 138 & 133 & & 6 & 15 & Nitrogen limitation & Converti et al. (2009) \\
\hline Cyclotella cryptica & - & - & & 18 & 38 & Silicon limitation & Griffiths and Harrison (2009) \\
\hline Dunaliella tertiolecta ATCC 30929 & - & - & & 60 & 70 & High salinity & Takagi et al. (2006) \\
\hline \multirow[t]{2}{*}{ Nannochloropsis oculata } & 127 & 73 & & 8 & 14 & High temperature & Converti et al. (2009) \\
\hline & 127 & 103 & & 8 & 16 & Nitrogen limitation & Converti et al. (2009) \\
\hline Nannochloropsis sp. & 633 & 457 & & 7 & 9 & High carbon dioxide & Hu and Gao (2003) \\
\hline Nannochloropsis sp. F\&M-M24 & 360 & 300 & & 32 & 60 & Nitrogen limitation & Rodolfi et al. (2009) \\
\hline Navicula saprophila & - & - & & 24 & 49 & Silicon limitation & Griffiths and Harrison (2009) \\
\hline Neochloris oleoabundans & 630 & 400 & & 16 & 34 & Nitrogen limitation & Li et al. (2008a) \\
\hline Scenedesmus obiquus CNW-N & 841 & 732 & & 12 & 22 & Nitrogen limitation & Ho et al. (2012) \\
\hline Scenedesmus sp. LX1 & $37-64$ & 27 & & $23-28$ & 53 & Phosphorous limitation & Xin et al. (2010) \\
\hline
\end{tabular}

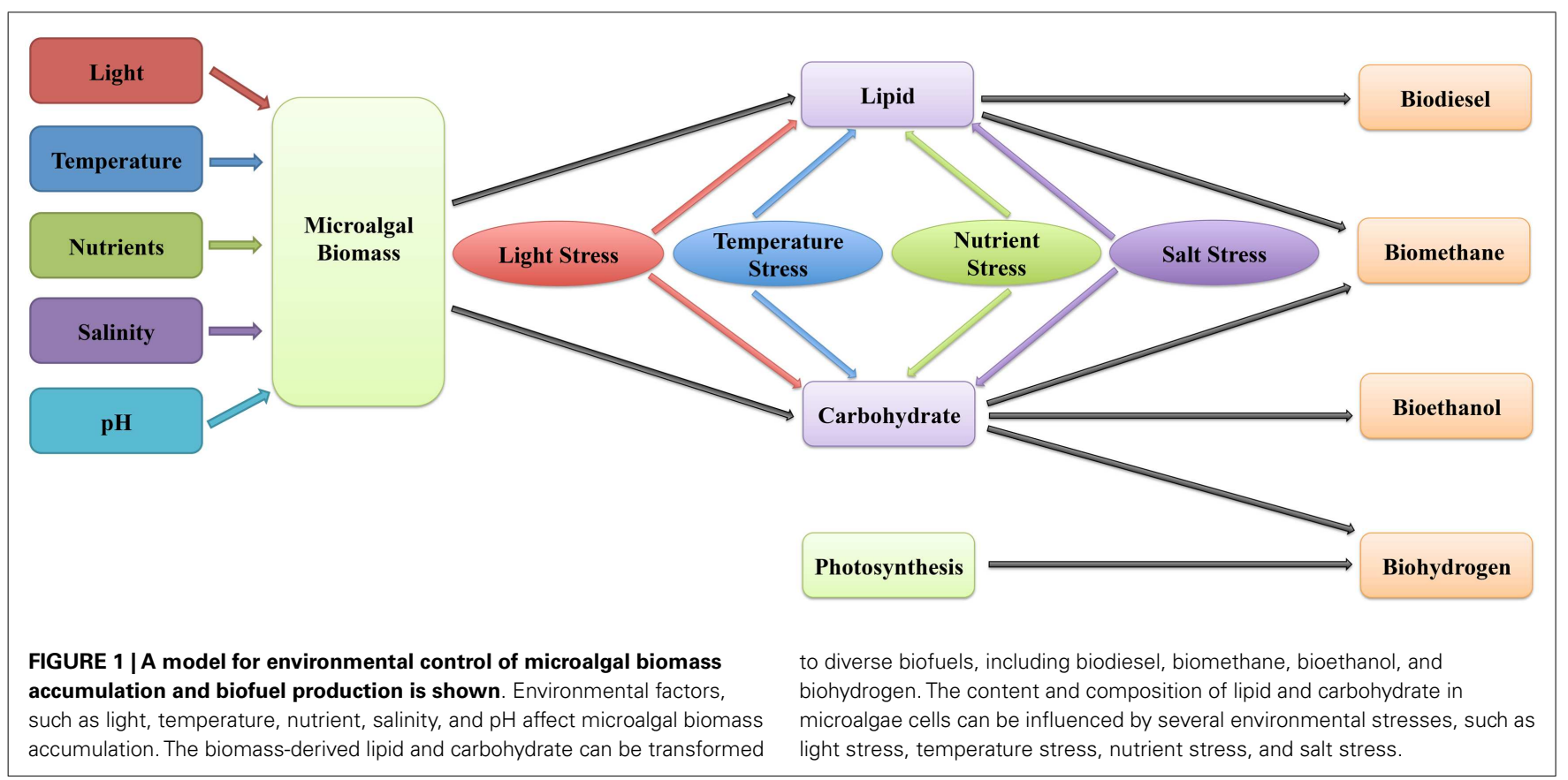


photosynthesis and the biosynthesis and accumulation of biomolecules such as lipids, carbohydrates, and biohydrogen.

\section{LIGHT}

Light is the basic energy source for photoautotrophic organisms, and the intensity of light is one of the key parameters affecting photosynthetic activity (Falkowski and Owens, 1980; Richardson et al., 1983; Post et al., 1985). The growth rate of the microalgae culture increases with increased light intensities, until saturating light (generally around $200-400 \mu \mathrm{E}$ ) is reached (Radakovits et al., 2010). Oversaturating light can lead to the formation of reactive oxygen species (ROS), which is harmful for microalgae cells (photoinhibition), and thereby, decrease the biomass productivity (Stanier and Cohenbazire, 1977; Goldman, 1979; Richmond, 2000).

\section{TEMPERATURE}

Although microalgae are able to survive at a variety of temperatures, optimal temperature for growth is limited to a narrow range $\left(20-30^{\circ} \mathrm{C}\right)$ (Singh et al., 2012). Generally, in optimal temperature range, rise in temperature leads to improved microalgal biomass production. Temperatures above the optimal range cause growth declines, in severe conditions, even kill microalgae cells. However, low temperatures seem to reduce the biomass loss caused by respiration during dark periods (Weissman and Goebel, 1985; Raven and Geider, 2006; Chisti, 2007). Therefore, high biomass accumulation can be achieved by increasing the temperature to optimal in the morning (to enhance productivity during the day) and decreasing the temperature at night (to avoid biomass loss) (Hu, 2004).

\section{NUTRIENTS}

Nutrients supplied to microalgal cultures include macronutrients (such as nitrogen, phosphorus, carbon, and sulfur) and micronutrients (such as iron, zinc, copper, and cobalt). Nutrient limitation may cause morphological and physiological changes of microalgae cells, and therefore decrease the growth rates and biomass production. Nitrogen and phosphorus are the most important nutrients required for microalgae growth, and the ratio of nitrogen to phosphorus $(\mathrm{N}: \mathrm{P})$ can directly control the nutrient limitation status (Rhee, 1978; Wijffels and Barbosa, 2010). Nitrogen is involved in the biosynthesis nucleus acids, proteins, and photosynthetic pigments. Nitrogen limitation decreases the synthesis of photosynthetic proteins and pigments, therefore affects the yield of microalgal biomass (Berges et al., 1996; Saha et al., 2003; Li et al., 2008a). Phosphorus is essential in a variety of cellular metabolic processes, and phosphorus limitation affects the growth and development of microalgae (Geider and La Roche, 2002; Litchman et al., 2003; Hu, 2004). Carbon dioxide is necessary for photosynthesis, but it will become harmful if in excess. In addition, the carbon metabolic mode (autotrophic, mixotrophic, or heterotrophic) also affects the growth rates of microalgae (Chojnacka and Marquez-Rocha, 2004). Sulfur is essential for photosynthesis, protein synthesis, and lipid metabolism. It has been reported that sulfur limitation can limit cell division of microalgae (Yildiz et al., 1994; Ariño et al., 1995). Iron plays a key role in photosynthetic electron transport chain, and its limitation leads to defects in photosynthesis (van Oijen et al., 2004; Liu et al., 2008). However, excessive iron may result in oxidative damage to the cells (Fenton, 1894; Choudhary et al., 2007).

\section{OTHER ENVIRONMENTAL FACTORS}

Environmental factors, such as salinity and $\mathrm{pH}$ are also important for microalgae biomass accumulation. Different microalgae species can tolerate different ranges of salt concentrations (Kirst, 1989). Excess salinity inhibits photosynthesis, thus reduces the yield of biomass (Vonshak and Richmond, 1981; Gilmour et al., 1984; Kirst, 1989; Endo et al., 1995; Cho et al., 2007; Rao et al., 2007). The $\mathrm{pH}$ range optimal for microalgal growth is narrow (for most microalgae, is between 8.2 and 8.7) and strain-specific (Pedersen and Hansen, 2003; Havlik et al., 2013). The pH in microalgal cultures rise steadily during the day as carbon dioxide is consumed through photosynthesis. It has been found that $\mathrm{pH}$ also impacts the availability and absorption of nutrients such as iron and carbon (Coleman and Colman, 1981; Lee and Pirt, 1984; Wu et al., 2012).

\section{ENVIRONMENTAL STRESSES AFFECTING MICROALGAL BIOFUEL PRODUCTIVITY}

The composition of microalgal biomass (such as biofuel-related lipids and carbohydrates) varies with the environmental conditions. Numerous studies have described utilizing environmental stresses (e.g., light stress, temperature stress, nutrient stress, and salt stress) to improve microalgal biofuel production (Table 1; Figure 1).

\section{LIGHT STRESS}

Microalgae grown under different light conditions exhibit remarkable changes in their chemical composition. Typically, the amount of poly unsaturated fatty acids (structural lipids) increases under low light conditions, whereas high light promotes the accumulation of saturated and mono-unsaturated fatty acids (storage lipids) (Spoehr and Milner, 1949; Orcutt and Patterson, 1974; Sukenik et al., 1989, 1993; Walsh et al., 1997; Khotimchenko and Yakovleva, 2005). Because saturated and mono-unsaturated fatty acids are preferred sources for biodiesel, it may be feasible to use relatively high light intensities to improve biodiesel yield. It has also been reported that the content of carbohydrate in Scenedesmus obliquus CNW-N increased from 16.3 to $22.4 \%$ after exposure to high light (Ho et al., 2012).

\section{TEMPERATURE STRESS}

Temperature can affect the lipid content in microalgae. Several microalgae, such as Ochromonas danica and Nannochloropsis oculata, have been found to increase their lipid content (37 and $89 \%$ increase, respectively) with increasing temperature (Aaronson, 1973; Converti et al., 2009). Besides, the composition of lipid can also be altered by temperature. Similar to the impact of light on lipid composition, low temperatures tend to increase the degree of unsaturation in fatty acid, whereas high temperatures improve the saturation of fatty acids (Sato et al., 1979; Wada and Murata, 1990; Renaud et al., 2002; Liu et al., 2005). Therefore, a suitably high temperature seems to promote the production of high quantity (high total lipid yield) and high quality (high saturation degrees 
of fatty acids) biodiesels. Temperature also influences the level of carbohydrates in microalgae, for example, the carbohydrate content in Spirulina sp. increased by $50 \%$ when the temperature was increased from 25 to $40^{\circ} \mathrm{C}$ (Ogbonda et al., 2007).

\section{NUTRIENT STRESS}

When grown under nutrient-stress conditions, microalgae change their metabolic strategies and biochemical composition. Consequently, the improved production of desired biofuels can be achieved by manipulating nutrient conditions.

\section{Nitrogen}

Nitrogen is critical for protein biosynthesis. However, under nitrogen-limiting conditions, most of the carbon fixed in photosynthesis is used to synthesize lipids or carbohydrates, instead of proteins. Nitrogen is considered to be the most important nutrient affecting lipid metabolism in microalgae. It has been reported that a variety of microalgae species increase the accumulation of lipids after nitrogen deprivation. For instance, lipid content in Neochloris oleoabundans and Nannochloropsis sp. F\&M-M24 increased about twofold and onefold, respectively, after nitrogen deprivation (Li et al., 2008a; Rodolfi et al., 2009). Nitrogen limitation also leads to the enhanced biosynthesis of carbohydrates in several microalgal species, such as a fourfold increase in carbohydrate content in Tetraselmis subcordiformis, and a $29 \%$ increase in carbohydrate content in S. obliquus CNW-N (Ji et al., 2011; Ho et al., 2012). Additionally, many cyanobacteria can produce hydrogen as a byproduct of nitrogen fixation when grown under nitrogenlimiting conditions (Das and Veziroglu, 2001; Dutta et al., 2005; Abed et al., 2009).

\section{Phosphorous}

Phosphorous is involved in many cellular metabolic processes. It has been found that phosphorous limitation results in increased accumulation of lipids in microalgal cells, for example, Scenedesmus sp. LX1 accumulated up to 53\% lipid under phosphorus-limiting conditions, whereas it only contained 2528\% lipid under phosphorus-replete conditions (Xin et al., 2010). In addition, Markou et al. (2012b) have shown that the carbohydrate content in Arthrospira (Spirulina) platensis increased from 11 to $67 \%$ after transfer to phosphorous-limiting medium.

\section{Sulfur}

Sulfur is one of the most significant nutrients that affect the biohydrogen production in microalgae. Sulfur limitation causes anaerobic environment inside microalgae cells, thus induces the activity of hydrogenase and the release of hydrogen (Dutta et al., 2005; Esquível et al., 2011). Therefore, sulfur-limiting conditions have been applied to increase hydrogen productivity in many microalgae species, such as Gloeocapsa alpicola, Synechocystis sp. PCC 6803, Chlamydomonas reinhardtii, Chlamydomonas noctigama and Chlamydomonas euyale (Antal and Lindblad, 2005; Laurinavichene et al., 2006; Skjånes et al., 2008). It has been also found that total fatty acid content in C. reinhardtii doubled after exposure to sulfur limitation (Matthew et al., 2009). Furthermore, Brányiková et al. (2011) reported that Chlorella vulgaris cells synthesized 50\% more starch under sulfur-limiting conditions than under sulfur-replete conditions.

\section{Carbon}

Carbon is thought to influence the activity of nitrogenase and therefore the nitrogenase-dependent hydrogen production (Dutta et al., 2005). Moreover, different amounts and sources of carbon have been shown to affect both the content and the composition of lipids in microalgae cells. It has been reported that high concentration of carbon dioxide induced the accumulation of saturated fatty acids, whereas low concentration of carbon dioxide facilitated the production of unsaturated fatty acids (Tsuzuki et al., 1990; Riebesell et al., 2000; Hu and Gao, 2003). Certain microalgae are able to use organic carbon instead of carbon dioxide as the carbon source for heterotrophic growth. It was found that heterotrophically grown Chlorella cells synthesized about $280 \%$ more lipids and $45 \%$ more carbohydrates than did autotrophically grown cells (Miao and $\mathrm{Wu}, 2006$ ).

\section{Trace mineral nutrients}

Trace mineral elements may affect the accumulation of lipids and carbohydrates in numerous microalgae. It has been found that the content of glucose in Agmenellum quadruplicatum increased from 5 to $45 \%$ in response to iron limitation (Hardie et al., 1983), whereas excess iron caused up to sevenfold increase in lipid content in C. vulgaris (Liu et al., 2008). It has also been reported that silicon limitation resulted in increased lipid content in many diatom species, such as 89,110 , and $104 \%$ increase in lipid content in Chaetoceros muelleri, Cyclotella cryptica, and Navicula saprophila, respectively (Griffiths and Harrison, 2009). Additionally, trace metals, such as iron, nickel, magnesium, molybdenum, and zinc are important for nitrogenase-catalyzed hydrogen production (Horner et al., 2002; Lin and Lay, 2005; Carrieri et al., 2008).

\section{SALT STRESS}

Salt has been shown to play an important role in the production of various biofuels. Carrieri et al. (2010) found that high salt concentration increased ethanol production by 121 -fold compared to low salt concentration in the cyanobacterium A. (Spirulina) maxima. It is also known that many microalgae produce low molecular weight carbohydrates in response to salt stresses (Warr et al., 1985; Stal and Reed, 1987; Page-Sharp et al., 1998; Rao et al., 2007). Besides, salt stress is able to influence lipid content and composition in microalgae cells. It has been observed that elevated salinity increased lipid content from 60 to $70 \%$ in Dunaliella tertiolecta ATCC 30929 (Takagi et al., 2006). In addition, high salinity tends to induce the saturation of fatty acid, thus increase the productivity of biodiesels (Xu and Beardall, 1997; Chen et al., 2008).

\section{COMBINATION OF MULTIPLE STRESS FACTORS}

Since the impacts of different environmental stresses on biofuel production are additive, combined application of multiple stress factors might obtain better effect on improving the yield of desired biofuel products than the application of single stress factor. Recently, more and more research has been focused on the cumulative effect of multiple environmental stresses on microalgal biofuel production. Pal et al. (2011) found that the productivity of total lipids reached to the maximum when employed high light stress and high salinity stress simultaneously to Nannochloropsis 
sp. cultures. Sun et al. (2014) used nitrogen starvation in conjunction with high light to achieve the maximal triacylglyceride and carbohydrate production in N. oleoabundans HK-129.

\section{PERSPECTIVES - A BALANCE BETWEEN BIOMASS ACCUMULATION AND BIOFUEL PRODUCTION}

Although applying environmental stress that can increase the production of microalgal biofuels, this is generally at the expense of decreased biomass yield. Consequently, the tradeoff between biomass accumulation and biofuel productivity is important for satisfactory biofuel production by microalgae.

In order to achieve optimum conditions for microalgal biofuel production, a two-phased cultivation method was proposed (Benemann and Oswald, 1996). In this method, the microalgae are grown under normal conditions in the first phase for biomass accumulation, followed by culturing under environmental-stress conditions in the second phase for desired biofuel production. By doing this, the microalgae can produce maximum biofuels without obvious biomass reduction. In the research performed by Rodolfi et al. (2009), a nutrient-replete first phase and a nitrogen-limiting second phase were used to increase both lipid content and areal lipid productivity in Nannochloropsis sp. F\&M-M24. Dragon and co-workers used nitrogen- and iron-sufficient medium in the first phase to achieve high cell growth, then introduced nitrogen- and iron-limitation in the second phase to boost starch accumulation in C. vulgaris (Dragone et al., 2011).

Another balanced approach is using stress-tolerant microalgae strains for biofuel production. Many genes have been reported to be involved in stress responses and adaptation. It is likely that genetic manipulation of these genes might confer stress tolerance characteristics to microalgae. For example, glutathione peroxidase is an antioxidant enzyme, which plays an important role in protecting cells against oxidative damage. It has been reported that overexpression of glutathione peroxidase led to improved tolerance to high light stress, low temperature stress, and high salinity stress in transgenic plants (Takeda et al., 2003; Yoshimura et al., 2004). Another example is $p f_{s} R$ (photosynthesis, Fe homeostasis, and stress-response regulator) in the cyanobacterium Synechocystis sp. PCC 6803. Inactivation of $p f s R$ resulted in stronger iron buffering capacity, and hence, improved resistance to iron limitation in Synechocystis sp. PCC 6803 (Jantaro et al., 2006). The photoinhibition caused by high light is always an important consideration when culturing microalgae, thus intensive efforts have been devoted to increase the tolerance of microalgae to high light-radiation. It has been shown that the Chlamydomonas mutants with reduced light-harvesting pigment or with truncated antenna size exhibited increased tolerance to high light and improved biomass productivity (Nakajima et al., 2001; Polle et al., 2002). The application of stress-tolerant strains not only makes the environmental-stress conditions suitable for both biomass accumulation and biofuels production but also prevents contamination, which reduces biomass production. The stress-tolerant microalgae strains, especially the strains thriving under reduced or limited nutrient conditions, such as the $p f s R$ mutant, can outcompete other species, thus keeping desired microalgal culture in relatively pure conditions.

Growing microalgae under optimized stress conditions (such as a proper combination of nutrient limitation and light stress) can reduce the cultivation cost, maximize the accumulation of biofuel materials, and avoid contamination by competing out unwanted organisms, therefore offers a sustainable strategy for improving microalgal biofuel production. A comprehensive lifecycle assessment of the production processes (Singh and Olsen, 2011; Singh et al., 2011c, 2013) and appropriate policy supports, such as increasing funding for environmental-stress research and pilot studies, encouraging the utilization of environmental factors for sustainable biofuel production, promoting the development of high-efficient and cost-effective microalgae cultivation methods, and offering economic incentives (for example, tax exemptions) for microalgal biofuels to attract industry interest, will advance the key technologies in harnessing environmental stresses to promote biofuel production at commercial scale.

\section{REFERENCES}

Aaronson, S. (1973). Effect of incubation temperature on the macromolecular and lipid content of the phytoflagellate Ochromonas danica. J. Phycol. 9, 111-113. doi:10.1111/j.0022-3646.1973.00111.x

Abed, R. M. M., Dobretsov, S., and Sudesh, K. (2009). Applications of cyanobacteria in biotechnology. J. Appl. Microbiol. 106, 1-12. doi:10.1111/j.1365-2672.2008. 03918.x

Alzate, M. E., Munoz, R., Rogalla, F., Fdz-Polanco, F., and Pérez-Elvira, S. I. (2012). Biochemical methane potential of microalgae: influence of substrate to inoculum ratio, biomass concentration and pretreatment. Bioresour. Technol. 123, 488-494. doi:10.1016/j.biortech.2012.06.113

Amin, S. (2009). Review on biofuel oil and gas production processes from microalgae. Energy Convers. Manag. 50, 1834-1840. doi:10.1016/j.enconman. 2009.03.001

Antal, T. K., and Lindblad, P. (2005). Production of $\mathrm{H}_{2}$ by sulphur-deprived cells of the unicellular cyanobacteria Gloeocapsa alpicola and Synechocystis sp. PCC 6803 during dark incubation with methane or at various extracellular pH. J. Ferment. Bioeng. 98, 114-120. doi:10.1111/j.1365-2672.2004.02431.x

Ariño, X., Ortega-Calvo, J., Hernandez-Marine, M., and Saiz-Jimenez, C. (1995). Effect of sulfur starvation on the morphology and ultrastructure of the cyanobacterium Gloeothece sp. PCC 6909. Arch. Microbiol. 163, 447-453. doi:10.1007/ BF00272134

Benemann, J. R. (2000). Hydrogen production by microalgae. J. Appl. Phycol. 12, 291-300. doi:10.1023/A:1008175112704

Benemann, J. R., and Oswald, W. J. (1996). Systems and Economic Analysis of Microalgae Ponds for Conversion of Carbon Dioxide to Biomass (Final Report: Grant No. DEFG22 93PC93204). Pittsburgh, PA: Pittsburgh Energy Technology Centre, US Department of Energy.

Berges, J. A., Charlebois, D. O., Mauzerall, D. C., and Falkowski, P. G. (1996). Differential effects of nitrogen limitation on photosynthetic efficiency of photosystems I and II in microalgae. Plant Physiol. 110, 689-696. doi:10.1104/pp.110.2.689

Brányiková, I., Maršálková, B., Doucha, J., Brányik, T., Bišová, K., Zachleder, V., et al. (2011). Microalgae-novel highly efficient starch producers. Biotechnol. Bioeng. 108, 766-776. doi:10.1002/bit.23016

Broch, A., Jena, U., Hoekman, S. K., and Langford, J. (2014). Analysis of solid and aqueous phase products from hydrothermal carbonization of whole and lipidextracted algae. Energies 7, 62-79. doi:10.3390/en7010062

Carrieri, D., Ananyev, G., Garcia Costas, A. M., Bryant, D. A., and Dismukes, G. C. (2008). Renewable hydrogen production by cyanobacteria: nickel requirements for optimal hydrogenase activity. Int. J. Hydrogen Energy 33, 2014-2022. doi:10.1016/j.ijhydene.2008.02.022

Carrieri, D., Momot, D., Brasg, I. A., Ananyev, G., Lenz, O. B., Bryant, D. A., et al. (2010). Boosting autofermentation rates and product yields with sodium stress cycling: application to renewable fuel production by cyanobacteria. Appl. Environ. Microbiol. 76, 6455-6462. doi:10.1128/AEM.00975-10

Chen, G. Q., Jiang, Y., and Chen, F. (2008). Salt-induced alterations in lipid composition of diatom Nitzschia laevis (Bacillariophyceae) under heterotrophic culture condition. J. Phycol. 44, 1309-1314. doi:10.1111/j.1529-8817.2008.00565.x

Chisti, Y. (2007). Biodiesel from microalgae. Biotechnol. Adv. 25, 294-306. doi:10. 1016/j.biotechadv.2007.02.001 
Cho, S., Ji, S. C., Hur, S., Bae, J., Park, I. S., and Song, Y. C. (2007). Optimum temperature and salinity conditions for growth of green algae Chlorella ellipsoidea and Nannochloris oculata. Fish. Sci. 73, 1050-1056. doi:10.1111/j.1444-2906.2007. 01435.x

Chojnacka, K., and Marquez-Rocha, F. J. (2004). Kinetic and stoichiometric relationships of the energy and carbon metabolism in the culture of microalgae. Biotechnol. Adv. 3, 21-34. doi:10.3923/biotech.2004.21.34

Choudhary, M., Jetley, U. K., Khan, M. A., Zutshi, S., and Fatma, T. (2007). Effect of heavy metal stress on proline, malondialdehyde, and superoxide dismutase activity in the cyanobacterium Spirulina platensis-S5. Ecotoxicol. Environ. Saf. 66, 204-209. doi:10.1016/j.ecoenv.2006.02.002

Coleman, J. R., and Colman, B. (1981). Inorganic carbon accumulation and photosynthesis in a blue-green alga as a function of external pH. Plant Physiol. 67, 917-921. doi:10.1104/pp.67.5.917

Converti, A., Casazza, A. A., Ortiz, E. Y., Perego, P., and Borghi, M. D. (2009). Effect of temperature and nitrogen concentration on the growth and lipid content of Nannochloropsis oculata and Chlorella vulgaris for biodiesel production. Chem. Eng. Process. 48, 1146-1151. doi:10.1016/j.cep.2009.03.006

Costa, J. A. V., and de Morais, M. G. (2011). The role of biochemical engineering in the production of biofuels from microalgae. Bioresour. Technol. 102, 2-9. doi:10.1016/j.biortech.2010.06.014

Das, D., and Veziroglu, T. N. (2001). Hydrogen production by biological processes: a survey of literature. Int. J. Hydrogen Energy 26, 13-28. doi:10.1016/S03603199(00)00058-6

Day, J. G., Slocombe, S. P., and Stanley, M. S. (2011). Overcoming biological constraints to enable the exploitation of microalgae for biofuels. Bioresour. Technol. 109, 245-251. doi:10.1016/j.biortech.2011.05.033

de Godos, I., Blanco, S., García-Encina, P. A., Becares, E., and Muñoz, R. (2009). Long-term operation of high rate algal ponds for the bioremediation of piggery wastewaters at high loading rates. Bioresour. Technol. 100, 4332-4339. doi:10.1016/j.biortech.2009.04.016

Deng, M., and Coema, J. R. (1999). Ethanol synthesis by genetic engineering in cyanobacteria. Appl. Environ. Microbiol. 65, 523-528.

Dismukes, G. C., Carrieri, D., Bennette, N., Ananyev, G. M., and Posewitz, M. C. (2008). Aquatic phototrophs: efficient alternatives to land-based crops for biofuels. Curr. Opin. Biotechnol. 19, 235-240. doi:10.1016/j.copbio.2008.05.007

Dragone, G., Fernandes, B. D., Abreu, A. P., Vicente, A. A., and Teixeira, J. A. (2011). Nutrient limitation as a strategy for increasing starch accumulation in microalgae. Appl. Energ. 88, 3331-3335. doi:10.1016/j.apenergy.2011.03.012

Dutta, D., De, D., Chaudhuri, S., and Bhattacharya, S. K. (2005). Hydrogen production by cyanobacteria. Microb. Cell Fact. 4, 1-11. doi:10.1186/1475-2859-4-36

Endo, T., Schreiber, U., and Asada, K. (1995). Suppression of quantum yield of photosystem II by hyperosmotic stress in Chlamydomonas reinhardtii. Plant Cell Physiol. 36, 1253-1258.

Esquível, M. G., Amaro, H. M., Pinto, T. S., Fevereiro, P. S., and Malcata, F. X. (2011). Efficient $\mathrm{H}_{2}$ production via Chlamydomonas reinhardtii. Trends Biotechnol. 29, 595-600. doi:10.1016/j.tibtech.2011.06.008

Falkowski, P. G., and Owens, T. G. (1980). Light-shade adaptation: two strategies in marine phytoplankton. Plant Physiol. 66, 592-595. doi:10.1104/pp.66.4.592

Fenton, H. J. H. (1894). Oxidation of tartaric acid in presence of iron. J. Chem. Soc. 65, 899-910. doi:10.1039/CT8946500899

Gavrilescu, M., and Chisti, C. (2005). Biotechnology - a sustainable alternative for chemical industry. Biotechnol. Adv. 23, 471-499. doi:10.1016/j.biotechadv.2005. 03.004

Geider, R. J., and La Roche, J. (2002). Redfield revisited: variability of C:N:P in marine microalgae and its biochemical basis. Eur. J. Phycol. 37, 1-17. doi:10.1017/S0967026201003456

Gilmour, D. J., Hipkins, M. F., and Boney, A. D. (1984). The effect of osmotic and ionic stress on the primary processes of photosynthesis in Dunaliella tertiolecta. J. Exp. Bot. 35, 18-27. doi:10.1093/jxb/35.1.18

Goldman, J. C. (1979). Outdoor mass algal cultures-II, photosynthetic yield limitations. Water Res. 11, 119-136. doi:10.1016/0043-1354(79)90083-6

Gong, Y., and Jiang, M. (2011). Biodiesel production with microalgae as feedstock: from strains to biodiesel. Biotechnol. Lett. 33, 1269-1284. doi:10.1007/s10529011-0574-z

Greenwell, H. C., Laurens, L. M. L., Shields, R. J., Lovitt, R. W., and Flynn, K. J. (2010). Placing microalgae on the biofuels priority list: a review of the technological challenges. J. R. Soc. Interface 7, 703-726. doi:10.1098/rsif.2009.0322
Griffiths, M. J., and Harrison, S. T. L. (2009). Lipid productivity as a key characteristic for choosing algal species for biodiesel production. J. Appl. Phycol. 21, 493-507. doi:10.1007/s10811-008-9392-7

Guschina, I. A., and Harwood, J. L. (2006). Lipids and lipid metabolism in eukaryotic algae. Prog. Lipid Res. 45, 160-186. doi:10.1016/j.plipres.2006.01.001

Hall, D. O., Markov, S. A., Watanabe, Y., and Rao, K. K. (1995). The potential applications of cyanobacterial photosynthesis for clean technologies. Photosyn. Res. 46, 159-167. doi:10.1007/BF00020426

Hardie, L. P., Balkwill, D. L., and Stevens, S. E. (1983). Effects of iron starvation on the physiology of the cyanobacterium Agmenellum quadruplicatum. Appl. Environ. Microbiol. 45, 999-1006.

Havlik, I., Lindner, P., Scheper, T., and Reardon, K. F. (2013). On-line monitoring of large cultivations of microalgae and cyanobacteria. Trends Biotechnol. 31, 406-414. doi:10.1016/j.tibtech.2013.04.005

Heilmann, S. M., Davis, H. T., Jader, L. R., Lefebvre, P. A., Sadowsky, M. J., Schendel, F. J., et al. (2010). Hydrothermal carbonization of microalgae. Biomass Bioenergy 34, 875-882. doi:10.1016/j.biombioe.2010.01.032

Hemschemeier, A., Melis, A., and Happe, T. (2009). Analytical approaches to photobiological hydrogen production in unicellular green algae. Photosyn. Res. 102, 523-540. doi:10.1007/s11120-009-9415-5

Ho, S. H., Chen, C. Y., and Chang, J. S. (2012). Effect of light intensity and nitrogen starvation on $\mathrm{CO}_{2}$ fixation and lipid/carbohydrate production of an indigenous microalgae Scenedesmus obliquus CNW-N. Bioresour. Technol. 113, 244-252. doi:10.1016/j.biortech.2011.11.133

Horner, D. S., Heil, B., Happe, T., Happe, T., and Embley, T. M. (2002). Iron hydrogenases - ancient enzymes in modern eukaryotes. Trends Biochem. Sci. 27, 148-153. doi:10.1016/S0968-0004(01)02053-9

$\mathrm{Hu}, \mathrm{H}$., and Gao, K. (2003). Optimization of growth and fatty acid composition of a unicellular marine picoplankton, Nannochloropsis sp., with enriched carbon sources. Biotechnol. Lett. 25, 421-425. doi:10.1023/A:1022489108980

Hu, Q. (2004). "Environmental effects on cell composition,” in Handbook of Microalgal Culture, ed. A. Richmond (Oxford: Blackwell), 83-93.

Hu, Q., Sommerfeld, M., Jarvis, E., Ghirardi, M., Posewitz, M., Seibert, M., et al. (2008). Microalgal triacylglycerols as feedstocks for biofuel production: perspectives and advances. Plant J. 54, 621-639. doi:10.1111/j.1365-313X.2008.03492.x

Jantaro, S., Ali, Q., Lone, S., and He, Q. (2006). Suppression of the lethality of high light to a quadruple HLI mutant by the inactivation of the regulatory protein PfsR in Synechocystis PCC 6803. J. Biol. Chem. 281, 30865-30874. doi:10.1074/jbc.M606252200

Jena, U., and Das, K. C. (2011). Comparative evaluation of thermochemical liquefaction and pyrolysis for bio-oil production from microalgae. Energy Fuel 25, 5472-5482. doi:10.1021/ef201373m

Jena, U., Das, K. C., and Kastner, J. R. (2011). Effect of operating conditions of thermochemical liquefaction on biocrude production from Spirulina platensis. Bioresour. Technol. 102, 6221-6229. doi:10.1016/j.biortech.2011.02.057

Ji, C.-F., Yu, X.-J., Chen, Z.-A., Xue, S., Legrand, J., and Zhang, W. (2011). Effects of nutrient deprivation on biochemical compositions and photo-hydrogen production of Tetraselmis subcordiformis. Int. J. Hydrogen Energy 36, 5817-5821. doi:10.1016/j.ijhydene.2010.12.138

Kapdan, I. K., and Kargi, F. (2006). Bio-hydrogen production from waste materials. Enzyme Microb. Technol. 38, 569-582. doi:10.1016/j.enzmictec.2005.09.015

Khotimchenko, S. V., and Yakovleva, I. M. (2005). Lipid composition of the red alga Tichocarpus crinitus exposed to different levels of photon irradiance. Phytochemistry 66, 73-79. doi:10.1016/j.phytochem.2004.10.024

Kirst, G. O. (1989). Salinity tolerance of eukaryotic marine algae. Annu. Rev. Plant Physiol. Plant Mol. Biol. 40, 21-53. doi:10.1146/annurev.pp.41.060190.000321

Laurinavichene, T. V., Fedorov, A. S., Ghiradi, M. L., Seibert, M., and Tsygankov, A. A. (2006). Demonstration of sustained hydrogen photoproduction by immobilized, sulfur-deprived Chlamydomonas reinhardtii cells. Int. J. Hydrogen Energy 31, 659-667. doi:10.1016/j.ijhydene.2005.05.002

Lee, Y. K., and Pirt, S. J. (1984). $\mathrm{CO}_{2}$ absorption rate in an algal culture: effect of pH. J. Phycol. 34, 28-32. doi:10.1002/jctb.280340105

Li, Y., Horsman, M., Wang, B., Wu, N., and Lan, C. Q. (2008a). Effects of nitrogen sources on cell growth and lipid accumulation of green alga Neochloris oleoabundans. Appl. Microbiol. Biotechnol. 81, 629-636. doi:10.1007/s00253-0081681- 1

Li, Y., Horsman, M., Wu, N., Lan, C. Q., and Dubois-Calero, N. (2008b). Biofuels from microalgae. Biotechnol. Prog. 24, 815-820. doi:10.1021/bp070371k 
Lin, C. Y., and Lay, C. H. (2005). A nutrient formulation for fermentative hydrogen production using anaerobic sewage sludge microflora. Int. J. Hydrogen Energy 30, 285-292. doi:10.1016/j.ijhydene.2004.03.002

Litchman, E., Steiner, D., and Bossard, P. (2003). Photosynthetic and growth responses of three freshwater algae to phosphorus limitation and day length. Freshw. Biol. 48, 2141-2148. doi:10.1046/j.1365-2427.2003.01157.x

Liu, X. J., Jiang, Y., and Chen, F. (2005). Fatty acid profile of the edible filamentous cyanobacterium Nostoc flagelliforme at different temperatures and developmental stages in liquid suspension culture. Process Biochem. 40, 371-377. doi:10.1016/j.procbio.2004.01.018

Liu, Z. Y., Wang, G. C., and Zhou, B. C. (2008). Effect of iron on growth and lipid accumulation in Chlorella vulgaris. Bioresour. Technol. 99, 4717-4722. doi:10.1016/j.biortech.2007.09.073

Markou, G., Angelidaki, I., and Georgakakis, D. (2012a). Microalgal carbohydrates: an overview of the influencing carbohydrates production, and of main bioconversion technologies for production of biofuels. Appl. Microbiol. Biotechnol. 96, 631-645. doi:10.1007/s00253-012-4398-0

Markou, G., Chatzipavlidis, I., and Georgakakis, D. (2012b). Carbohydrates production and bio-flocculation characteristics in cultures of Arthrospira (Spirulina) platensis: improvements through phosphorus limitation process. Bioenerg. Res. 5, 915-925. doi:10.1007/s12155-012-9205-3

Markou, G., and Georgakakis, D. (2011). Cultivation of filamentous cyanobacteria (blue-green algae) in agro-industrial wastes and waste-waters: a review. Appl. Energy 88, 3389-3401. doi:10.1016/j.apenergy.2010.12.042

Matthew, T., Zhou, W., Rupprecht, J., Lim, L., Thomas-Hall, S. R., Doebbe, A., et al. (2009). The metabolome of Chlamydomonas reinhardtii following induction of anaerobic $\mathrm{H}_{2}$ production by sulfur depletion. J. Biol. Chem. 284, 13415-13425. doi:10.1074/jbc.M109.003541

Miao, X., Wu, Q., and Yang, C. (2004). Fast pyrolysis of microalgae to produce renewable fuels. J. Anal. Appl. Pyrolysis 71, 855-863. doi:10.1016/j.jaap.2003.11.004

Miao, X. L., and Wu, Q. Y. (2006). Biodiesel production from heterotrophic microalgal oil. Bioresour. Technol. 97, 841-846. doi:10.1016/j.biortech.2005.04.008

Mulbry, W., Kondrad, S., Pizarro, C., and Kebede-Westhead, E. (2008). Treatment of dairy manure effluent using freshwater algae: algal productivity and recovery of manure nutrients using pilot-scale algal turf scrubbers. Bioresour. Technol. 99, 8137-8142. doi:10.1016/j.biortech.2008.03.073

Nakajima, Y., Tsuzuki, M., and Ueda, R. (2001). Improved productivity by reduction of the content of light-harvesting pigment in Chlamydomonas perigranulata. J. Appl. Phycol. 13, 95-101. doi:10.1023/A:1011192832502

Nigam, P. S., and Singh, A. (2011). Production of liquid biofuels from renewable resources. Prog. Energy Combust. Sci. 37, 52-68. doi:10.1016/j.pecs.2010.01.003

Ogbonda, K. H., Aminigo, R. E., and Abu, G. O. (2007). Influence of temperature and $\mathrm{pH}$ on biomass production and protein biosynthesis in a putative Spirulina sp. Bioresour. Technol. 98, 2207-2211. doi:10.1016/j.biortech.2006.08.028

Olaizola, M. (2003). Commercial development of microalgal biotechnology: from the test tube to the marketplace. Biomol. Eng. 20, 459-466. doi:10.1016/S13890344(03)00076-5

Ono, E., and Cuello, J. L. (2007). Carbon dioxide mitigation using thermophilic cyanobacteria. Biosyst. Eng. 96, 129-134. doi:10.1016/j.biosystemseng.2006.09. 010

Orcutt, D. M., and Patterson, G. W. (1974). Effect of light intensity upon Nitzschia closterium (Cylindrotheca fusiformis). Lipids 9, 1000-1003. doi:10.1007/ BF02533825

Packer, M. (2009). Algal capture of carbon dioxide; biomass generation as a tool for greenhouse gas mitigation with reference to New Zealand energy strategy and policy. Energy Policy 37, 3428-3437. doi:10.1016/j.enpol.2008.12.025

Page-Sharp, M., Behm, C. A., and Smith, G. D. (1998). Cyanophycin and glycogen synthesis in a cyanobacterial Scytonema species in response to salt stress. FEMS Microbiol. Lett. 160, 11-15. doi:10.1111/j.1574-6968.1998.tb12883.x

Pal, D., Khozin-Goldberg, I., Cohen, Z., and Boussiba, S. (2011). The effect of light, salinity, and nitrogen availability on lipid production by Nannochloropsis sp. Appl. Microbiol. Biotechnol. 90, 1429-1441. doi:10.1007/s00253-011-3170-1

Pedersen, M. F., and Hansen, P. J. (2003). Effects of high pH on the growth and survival of six marine heterotrophic protists. Mar. Ecol. Prog. Ser. 260, 33-41. doi:10.3354/meps260033

Polle, J. E. W., Kanakagiri, S., Jin, E. S., Masuda, T., and Melis, A. (2002). Truncated chlorophyll antenna size of the photosystems - a practical method to improve microalgal productivity and hydrogen production in mass culture. Int. J. Hydrogen Energy 27, 1257-1264. doi:10.1016/S0360-3199(02)00116-7

Post, A. F., Dubinsky, Z., Wyman, K., and Falkowski, P. G. (1985). Physiological responses of a marine planktonic diatom to transitions in growth irradiance. Mar. Ecol. Prog. Ser. 25, 141-149. doi:10.3354/meps025141

Quintana, N., Van der Kooy, F., Van de Rhee, M., Voshol, G., and Verpoorte, R. (2011). Renewable energy from cyanobacteria: energy production optimization by metabolic pathway engineering. Appl. Microbiol. Biotechnol. 91, 471-490. doi:10.1007/s00253-011-3394-0

Radakovits, R., Jinkerson, R. E., Darzins, A., and Posewitz, M. C. (2010). Genetic engineering of algae for enhanced biofuel production. Eukaryotic Cell 9, 486-501. doi:10.1128/EC.00364-09

Radmer, R. J., and Parker, B. C. (1994). Commercial applications of algae: opportunities and constraints. J. Appl. Phycol. 6, 93-98. doi:10.1007/BF02186062

Raja, R., Hemaiswarya, S., Ashok Kumar, N., Sridhar, S., and Rengasamy, R. (2008). A perspective on biotechnological potential of microalgae. Crit. Rev. Microbiol. 34, 34-77. doi:10.1080/10408410802086783

Rao, A. R., Dayananda, C., Sarada, R., Shamala, T. R., and Ravishankar, G. A. (2007). Effect of salinity on growth of green alga Botryococcus braunii and its constituents. Bioresour. Technol. 98, 560-564. doi:10.1016/j.biortech.2006.02. 007

Raven, J. A., and Geider, R. J. (2006). Temperature and algal growth. New Phytol. 110, 441-461. doi:10.1111/j.1469-8137.1988.tb00282.x

Rawat, I., Ranjith Kumar, R., Mutanda, T., and Bux, F. (2011). Dual role of microalgae: phycoremediation of domestic wastewater and biomass production for sustainable biofuels production. Appl. Energy 88, 3411-3424. doi:10.1016/j. apenergy.2010.11.025

Renaud, S. M., Thinh, L. V., Lambrinidis, G., and Parry, D. L. (2002). Effect of temperature on growth, chemical composition and fatty acid composition of tropical Australian microalgae grown in batch cultures. Aquaculture 211, 195-214. doi:10.1016/S0044-8486(01)00875-4

Rhee, G. Y. (1978). Effects of N:P atomic ratios and nitrate limitation on algal growth, cell composition, and nitrate uptake. Limnol. Oceanogr. 23, 10-25. doi:10.4319/lo.1978.23.1.0010

Richardson, K., Beardall, J., and Raven, J. A. (1983). Adaptation of unicellular algae to irradiance: an analysis of strategies. New Phytol. 93, 157-191. doi:10.1111/j.1469-8137.1983.tb03422.x

Richmond, A. (2000). Microalgal biotechnology at the turn of the millennium: a personal view. J. Appl. Phycol. 12, 441-451. doi:10.1023/A:1008123131307

Riebesell, U., Revill, A. T., Holdsworth, D. G., and Volkman, J. (2000). The effects of varying $\mathrm{CO}_{2}$ concentration on lipid composition and carbon isotope fractionation in Emiliania huxleyi. Geochim. Cosmochim. Acta 64, 4179-4192. doi:10.1016/S0016-7037(00)00474-9

Rodolfi, L., Zittelli, G. C., Bassi, N., Padovani, G., Biondi, N., Bonini, G., et al. (2009). Microalgae for oil: strain selection, induction of lipid synthesis and outdoor mass cultivation in a low-cost photobioreactor. Biotechnol. Bioeng. 102, 100-112. doi:10.1002/bit. 22033

Saha, S. K., Uma, L., and Subramanian, G. (2003). Nitrogen stress induced changes in the marine cyanobacterium Oscillatoria willei BDU 130511. FEMS Microbiol. Ecol. 45, 263-272. doi:10.1016/S0168-6496(03)00162-4

Sato, N., Murata, N., Yoshiro, M., and Nobuo, U. (1979). Effect of growth temperature on lipid and fatty acid compositions in the blue-green algae, Anabaena variabilis and Anacystis nidulans. Biochim. Biophys. Acta 572, 19-28. doi:10.1016/0005-2760(79)90196-6

Schenk, P. M., Thomas-Hall, S. R., Stephen, E., Marx, U. C., Mussgnug, J. H., Posten, C., et al. (2008). Second generation biofuels: high-efficiency microalgae for biodiesel production. Bioenerg. Res. 1,20-43. doi:10.1007/s12155008-9008-8

Scott, S. A., Davery, M. P., Dennis, J. S., Horst, I., Howe, C. J., Lea-Smith, D. J., et al. (2010). Biodiesel from algae: challenges and prospects. Curr. Opin. Biotechnol. 21, 277-286. doi:10.1016/j.copbio.2010.03.005

Sialve, B., Bernet, N., and Bernard, O. (2009). Anaerobic digestion of microalgae as a necessary step to make microalgal biodiesel sustainable. Biotechnol. Adv. 27, 409-416. doi:10.1016/j.biotechadv.2009.03.001

Singh, A., Nigam, P. S., and Murphy, J. D. (2011a). Renewable fuels from algae: an answer to debatable land based fuels. Bioresour. Technol. 102, 10-16. doi:10.1016/j.biortech.2010.06.032 
Singh, A., Nigam, P. S., and Murphy, J. D. (2011b). Mechanism and challenges in commercialization of algal biofuels. Bioresour. Technol. 102, 26-34. doi:10.1016/ j.biortech.2010.06.057

Singh, A., Olsen, S. I., and Nigam, P. S. (2011c). A viable technology to generate third-generation biofuel. J. Chem. Technol. Biotechnol. 86, 1349-1353. doi:10.1002/jctb. 2666

Singh, A., and Olsen, S. I. (2011). A critical review of biochemical conversion, sustainability and life cycle assessment of algal biofuels. Appl. Energy 88, 3548-3555. doi:10.1016/j.apenergy.2010.12.012

Singh, A., Olsen, S. I., and Pant, D. (2013). "Importance of life cycle assessment of renewable energy sources," in Life Cycle Assessment of Renewable Energy Sources, Green Energy and Technology Series, eds A. Singh, D. Pant, and S. I. Olsen (London: Springer-Verlag), 1-11.

Singh, A., Pant, D., Olsen, S. I., and Nigam, P. S. (2012). Key issues to consider in microalgae based biodiesel production. Energy Edu. Sci. Technol. Part A Energy Sci. Res. 29, 687-700.

Singh, N. K., and Dhar, D. W. (2011). Microalgae as second generation biofuel. A review. Agro. Sustain. Dev. 31, 605-629. doi:10.1007/s13593-011-0018-0

Singh, S., Bhushan, K. N., and Banerjee, U. C. (2005). Bioactive compounds from cyanobacteria and microalgae: an overview. Crit. Rev. Biotechnol. 25, 73-95. doi:10.1080/07388550500248498

Skjånes, K., Knutsen, G., Källqvist, T., and Lindblad, P. (2008). $\mathrm{H}_{2}$ production from marine and freshwater species of green algae during sulfur deprivation and considerations for bioreactor design. Int. J. Hydrogen Energy 33, 511-521. doi:10.1016/j.ijhydene.2007.09.040

Spoehr, H. A., and Milner, H. W. (1949). The chemical composition of Chlorella; effect of environmental conditions. Plant Physiol. 24, 120-149. doi:10.1104/pp. 24.1.120

Spolaore, P., Joannis-Cassan, C., Duran, E., and Isambet, A. (2006). Commercial applications of microalgae. J. Biosci. Bioeng. 101, 87-96. doi:10.1263/jbb.101.87

Stal, L. J., and Reed, R. H. (1987). Low-molecular mass carbohydrate accumulation in cyanobacteria from a marine microbial mat in response to salt. FEMS Microbiol. Lett. 45, 305-312. doi:10.1111/j.1574-6968.1987.tb02381.x

Stanier, R. Y., and Cohenbazire, G. (1977). Phototrophic prokaryotes-cyanobacteria. Annu. Rev. Microbiol. 31, 225-274. doi:10.1146/annurev.mi.31.100177.001301

Sukenik, A., Carmeli, Y., and Berner, T. (1989). Regulation of fatty acid composition by irradiance level in the eustigmatophyte Nannochloropsis sp. J. Phycol. 25, 686-692. doi:10.1111/j.0022-3646.1989.00686.x

Sukenik, A., Yamaguchi, Y., and Livne, A. (1993). Alterations in lipid molecular species of the marine eustigmatophyte Nannochloropsis sp. J. Phycol. 29, 620-626. doi:10.1111/j.0022-3646.1993.00620.x

Sun, X., Gao, Y., Xu, H., Liu, Y., Sun, J., Qiao, D., et al. (2014). Effect of nitrogenstarvation, light intensity and iron on triacylglyceride/carbohydrate production and fatty acid profile of Neochloris oleoabundans HK-129 by a two-stage process. Bioresour. Technol. 155, 204-212. doi:10.1016/j.biortech.2013.12.109

Takagi, M., Karseno, and Yoshida, T. (2006). Effect of salt concentration on intracellular accumulation of lipids and triacylglyceride in marine microalgae Dunaliella cells. J. Biosci. Bioeng. 101, 223-226. doi:10.1263/jbb.101.223

Takeda, T., Miyao, K., Tamoi, M., Kanaboshi, H., Miyasaka, H., and Shigeoka, S. (2003). Molecular characterization of glutathione peroxidase-like protein in halotolerant Chlamydomonas sp. W80. Physiol. Plant 117, 467-475. doi:10.1034/ j.1399-3054.2003.00075.x

Tsuzuki, M., Ohnuma, E., Sato, N., Takaku, T., and Kawaguchi, A. (1990). Effects of $\mathrm{CO}_{2}$ concentration during growth on fatty acid composition in microalgae. Plant Physiol. 93, 851-856. doi:10.1104/pp.93.3.851

van Oijen, T., van Leeuwe, M. A., Gieskes, W. W. C., and de Baar, H. J. W. (2004). Effects of iron limitation on photosynthesis and carbohydrate metabolism in the Antarctic diatom Chaetoceros brevis (Bacillariophyceae). Eur. J. Phycol. 39, 161-171. doi:10.1080/0967026042000202127
Vonshak, A., and Richmond, A. (1981). Photosynthetic and respiratory activity in Anacystis nidulans adapted to osmotic stress. Plant Physiol. 68, 504-505. doi:10.1104/pp.68.2.504

Wada, H., and Murata, N. (1990). Temperature-induced changes in the fatty acid composition of the cyanobacterium, Synechocystis PCC6803. Plant Physiol. 92, 1062-1069. doi:10.1104/pp.92.4.1062

Walker, T. L., Purton, S., Becker, D. K., and Collet, C. (2005). Microalgae as bioreactors. Plant Cell Rep. 24, 629-641. doi:10.1007/s00299-005-0004-6

Walsh, K., Jones, G. J., and Hugh, D. R. (1997). Effect of irradiance on fatty acid, carotenoid, total protein composition and growth of Microcystis aeruginosa. Phytochemistry 44, 817-824. doi:10.1016/S0031-9422(96)00573-0

Warr, S. R. C., Reed, R. H., and Stewart, W. D. P. (1985). Carbohydrate accumulation in osmotically stressed cyanobacteria (blue-green algae): interactions of temperature and salinity. New Phytol. 100, 285-292. doi:10.1111/j.1469-8137. 1985.tb02779.x

Weissman, J. C., and Goebel, R. P. (1985). Production of Liquid Fuels and Chemicals by Microalgae (Report SERI/STR-231-2649, Subcontract No. XK-3-03136, Contract No. DE-AC02-83CH10093). Golden, CO: Solar Energy Research Institute, Prepared for US Department of Energy, 116.

Wijffels, R. H., and Barbosa, M. J. (2010). An outlook on microalgal biofuels. Science 329, 796-799. doi:10.1126/science.1189003

Wu, Z., Zhu, Y., Huang, W., Zhang, C., Li, T., Zhang, Y., et al. (2012). Evaluation of flocculation induced by $\mathrm{pH}$ increase for harvesting microalgae and reuse of flocculated medium. Bioresour. Technol. 110, 496-502. doi:10.1016/j.biortech.2012. 01.101

Xin, L., Hong-ying, H., Ke, G., and Ying-xue, S. (2010). Effects of different nitrogen and phosphorus concentrations on the growth, nutrient uptake, and lipid accumulation of a freshwater microalgae Scenedesmus sp. Bioresour. Technol. 101, 5494-5500. doi:10.1016/j.biortech.2010.02.016

Xu, X. Q., and Beardall, J. (1997). Effect of salinity on fatty acid composition of a green microalgae from an Antarctic hypersaline lake. Phytochemistry 45, 655-658. doi:10.1016/S0031-9422(96)00868-0

Yildiz, F. H., Davies, J. P., and Grossman, A. C. (1994). Characterization of sulfate transport in Chlamydomonas reinhardtii during sulfur-limited and sulfursufficient growth. Plant Physiol. 104, 981-987. doi:10.1104/pp.104.3.981

Yoshimura, K., Miyao, K., Gaber, A., Takeda, T., Kanaboshi, H., Miyasaka, H., et al. (2004). Enhancement of stress tolerance in transgenic tobacco plants overexpressing Chlamydomonas glutathione peroxidase in chloroplasts or cytosol. Plant J. 37, 21-33. doi:10.1046/j.1365-313X.2003.01930.x

Conflict of Interest Statement: The authors declare that the research was conducted in the absence of any commercial or financial relationships that could be construed as a potential conflict of interest.

Received: 10 April 2014; paper pending published: 22 May 2014; accepted: 23 June 2014; published online: 07 July 2014.

Citation: Cheng D and He Q (2014) Assessment of environmental stresses for enhanced microalgal biofuel production - an overview. Front. Energy Res. 2:26. doi: 10.3389/fenrg.2014.00026

This article was submitted to Bioenergy and Biofuels, a section of the journal Frontiers in Energy Research.

Copyright (c) 2014 Cheng and He. This is an open-access article distributed under the terms of the Creative Commons Attribution License (CC BY). The use, distribution or reproduction in other forums is permitted, provided the original author(s) or licensor are credited and that the original publication in this journal is cited, in accordance with accepted academic practice. No use, distribution or reproduction is permitted which does not comply with these terms. 